\title{
Analysis of Factors That Influence The Interest of Buying Consumers At Sticky Rice Milk (Tansu) Stall in English Village Pare Kediri
}

\author{
Stevanus Gatot Supriyadi \\ Kahuripan University Kediri, East Java, Indonesia \\ Email: stevan.gatot@gmail.com \\ Nabilla Yuansa Pratiwi \\ Kahuripan University Kediri, East Java, Indonesia \\ Email: nabila.yuansa@gmail.com
}

\begin{abstract}
The purpose of this study is to determine the effect of factors in making a purchasing decision. The number of samples in this study were 45 samples. The analytical tool used is multiple linear regression. The results showed that Cultural Factors partially had a positive and significant effect on consumers' buying interest in the English village rice milk stall pare. The social factors partially have a positive and significant effect on consumer buying interest in the English village milk stick stall. Personal factors partially have no significant effect on consumers' buying interest in the English village rice milk stall pare. Cultural, social and personal factors have a simultaneous effect on consumers' buying interest in milk-stick stalls in the English village of Pare.
\end{abstract}

Keywords: cultural factors, social factors, personal factors, decision factors

\section{Introduction}

Companies that appear to focus on specializing in the types of culinary brands that they serve both their food and drinks, for example coffee shops at this time they really focus on the type of coffee they have in order to attract consumers to come to their shop. There are also types of culinary businesses that focus on serving glutinous milk products. Companies engaged in the business sector are trying to introduce food types to consumers (chendradewi, 2016).

As for the factors that influence consumer buying interest according to kotler (2009: 166), namely: (1) Cultural factors are consumers in buying a product, among others, a culture that includes subgroups consisting of national groups, religious groups, racial groups, and regional groups . (2) Social factors also affect someone in buying a product. Usually the one that affects socially is an item that is trending its model in the community such as sticky rice. (3) Personal factors are the most decisive factors in purchasing a product. these factors include age, and stages in the buyer's life cycle, work and economic conditions, personality and selfconcept.

According to Schiffman and Kanuk (2004: 25), explaining that external influences, awareness of needs, product introduction raises consumer buying interest. this external influence consists of marketing efforts and socio-cultural factors. Whereas according to Kotler and Keller (2003: 186) the consumer may also form the intention to buy the most pre-branded which means that consumers have the desire to buy a product based on a brand. In order to create consumer buying interest, the products offered by the company must be of high quality. The term quality itself 
International Journal of Economics, Business and Accounting Research (IJEBAR) .

Peer Reviewed - International Journal

Vol-2, Issue-3, 2018 (IJEBAR)

ISSN: 2614-1280, https://jurnal.stie-aas.ac.id/index.php/IJEBAR

contains various interpretations, because it has a number of levels: universal (same everywhere), culture (depending on cultural value systems), social (formed by individual social classes). Buying interest is a component of consumer behavior in the attitude of consumption, the tendency of respondents to act before a buying decision. Buying interest is a component of behavior in consuming.

As with the sticky rice shop or often called Tansu, it is a type of culinary business that focuses on milk sticky rice products. This glutinous rice stall is located in the English village of Tulungrejo village in the sub-district of Pare, a sticky rice milk stall that has been formed since about 5 years ago. Glutinous rice stalls or commonly called Tansu stalls are not a cafe with a magnificent building and also fancy menus, it is clearly illustrated by its name, which is a stall that describes exactly simple food by offering a simple food menu. The menu offered by Tansu is a typical English village milk stick. The name of the shop is also the designation of the one menu item.

In addition to sticky rice, there is also another menu that is still based on the same, namely sticky rice powder or original. The drinks offered are very simple, namely coffee, milk, and also cappuccino sachets that can be ordered in hot or cold conditions. With simple menu, you only need to spend too much money, which is only around Rp. 3000 for a portion of sticky rice and Rp. 2000 for a glass of drink.

This Tansu sticky rice stall also offers a place that is surrounded by rice fields creating a cool atmosphere that can eliminate all fatigue, fatigue and fatigue after a day of activities. This tansu stall is open from morning to evening which is always filled with visitors. This tansu stall is often an alternative place to study for the English village people.
But at this time many sticky rice entrepreneurs have sprung up, with many competitors making choices about which sticky rice products consumers will choose. In the English village there are also other sticky rice stalls from the usual to the wellknown one of which is the Oplostar sticky rice stall which is famous for its interesting places besides their business name being a brand that will fulfill their type of business to consumers and attract the community to meet their sticky rice shops.

The purpose of this study was to determine the effect of cultural factors, social factors, and personal factors on the decision to buy interest in tansu sticky rice stalls.

\section{Literature Review}

\subsection{Factors That Influence Purchases}

Factors that influence someone to make a purchase of a product. management needs to study these factors so that the marketing program can be more successful. These factors include cultural, social, personal factors (Kotler and Keller, 2009: 166). (1) Cultural Factor (cultur) is a basic determinant of one's desires and behavior. Each culture consists of several subcultures (subcultures) that provide more identification and socialization that is more specific to their members. Sub-cultures include nationality, religion, racial groups, and geographical regions. (2) Social factors are influenced by reference groups, families, as well as, social roles and status influence consumer behavior. Reference groups are all groups that have a direct (face to face) or indirect influence on the person's attitude or behavior. (3) Personal factors, buyer decisions are also influenced by personal characteristics. Personal factors include age and stages in the life cycle of the buyer, work and economy, personality and self-concept, and lifestyle and values 
International Journal of Economics, Business and Accounting Research (IJEBAR) .

Peer Reviewed - International Journal

Vol-2, Issue-3, 2018 (IJEBAR)

ISSN: 2614-1280, https://jurnal.stie-aas.ac.id/index.php/IJEBAR

\subsection{Buying Behavior}

According to Kotler and Keller (2009) there are four types of consumer buying behavior, namely:

a) Complex buying behavior

Complicated buying behavior requires high involvement in purchases by trying to realize the obvious changes among existing brands.

b) Purchasing behavior reduces inconvenience

This kind of buying behavior has a high involvement and consumers realize there are only a few differences between several brands.

c) Habitual buying behavior.

Consumers buy a product based on habits, not based on loyalty to the brand. Consumers have products repeatedly not because of product brands, but because they are familiar with the product. After buying, they do not reevaluate why they buy the product because they are not involved with the product.

d) Purchasing behavior that seeks variety.

This behavior has a low involvement, but there are still clear brand differences. Consumers behave with the aim of seeking diversity and not satisfaction. So the brand in this behavior is not something absolute.

\subsection{Interest in Buying}

According to Irwan, Pane (2011: 66-67) is "a strong desire to desire a very high heart to get something by means of sacrifice, get everything by paying money.

\section{Research Methods}

This study uses quantitative research. According to Suharsimi Arikunto (203: 27) explaining quantitative research as the name implies, many are required to use numbers, starting from data collection, interpretation of the data, and the appearance of other results, whose purpose is to find out what factors influence consumer buying interest.

The population in this study amounted to 45 students in the English village of Pare Kediri, East Java, where all the numbers from the population were used as research samples.

Operational definition, culture is a habit that humans learn as a member of society whose indicators include: Because it is practically consumed, because it is easy to obtain, Personal consumption. Consumed every day, consumed since childhood. Social is all human behavior that describes the interaction between individual humans and humans, whose indicators include the influence of friends, family influence, the influence of others, the influence of advertising on the internet. Personal, decision making is determined by each individual. Which indicator includes according to pocket money, affordable price, like it feels. Interest in buying desires followed by product purchases.

The collected data will be analyzed using statistical analysis techniques using the SPSS program, where the statistical formula used is Linear Multiple Regression.

\section{Results}

\subsection{Test $F$}

To test hypotheses simultaneously, an F test is performed which shows the influence of the bebes variable (X) simultaneously (simultaneously) on the dependent variable (Y). the form of hypothesis $\mathrm{F}$ test (simultaneous) to find out the independent variable $(\mathrm{X})$ consisting of $\mathrm{X}_{1}$ (culture), $\mathrm{X}_{2}$ (social), $\mathrm{X}_{3}$ (personal) variables to the dependent variable (Y), namely buying interest as follows: 
International Journal of Economics, Business and Accounting Research (IJEBAR) .

Peer Reviewed - International Journal

Vol-2, Issue-3, 2018 (IJEBAR)

ISSN: 2614-1280, https://jurnal.stie-aas.ac.id/index.php/IJEBAR

Tabel 1. Test $\mathrm{F}$

ANOVA $^{\mathrm{D}}$

\begin{tabular}{|r|r|r|r|r|r|}
\hline Model & $\begin{array}{r}\text { Sum of } \\
\text { Squares }\end{array}$ & Df & Mean \\
Square & $\mathrm{F}$ & Sig \\
\hline Regression & 51.588 & 3 & 17.196 & 13.767 & $.000^{\mathrm{a}}$ \\
Residual & 51.212 & 41 & 1.249 & & \\
Total & 102.800 & 44 & & & \\
\hline
\end{tabular}

a. Predictors: (Constant), X3, X1, X2

b. Dependent Variable: Y1

Based on table 1 above it is known that the value of the calculated model is 13,767 , while the value of Ftable is 0.2475 . because the value of Fcount is greater than Ftable, then Ho is rejected which means significant (influential), so it can be concluded that simultaneously (simultaneously) Variable $\mathrm{X}_{1}$ (culture), $\mathrm{X}_{2}$ (social), $\mathrm{X}_{3}$ (personal) to the dependent variable $(Y)$ is interest in buying.

\subsection{Test $t$}

To test the hypothesis used the t test which shows the effect partially from each independent variable on the dependent variable. At this stage, the effect of independent variables found in the model

formed is examined to determine whether the independent variable $(\mathrm{X})$ in the model partially has a significant effect on the dependent variable (Y). as below:

Table 2. Test $\mathrm{t}$

Coefficients $^{\mathrm{a}}$

\begin{tabular}{|l|l|r|r|r|r|r|}
\hline \multicolumn{2}{|l|}{ Model } & \multicolumn{2}{|c|}{$\begin{array}{c}\text { Unstandardized } \\
\text { Coefficients }\end{array}$} & $\begin{array}{c}\text { Standardized } \\
\text { Coefficients }\end{array}$ & \multirow{2}{*}{ T } & \multirow{2}{*}{ Sig. } \\
\cline { 2 - 5 } & \multicolumn{1}{|c|}{$\mathrm{B}$} & $\begin{array}{c}\text { Std. } \\
\text { Error }\end{array}$ & \multicolumn{1}{c|}{ Beta } & & \\
\hline \multirow{3}{*}{1} & (Constant) & 1.412 & 1.908 & & .740 & .463 \\
\cline { 2 - 7 } & $\mathrm{X} 1$ & .361 & .115 & .364 & 3.138 & .003 \\
\cline { 2 - 6 } & $\mathrm{X} 2$ & .390 & .116 & .441 & 3.360 & .002 \\
\cline { 2 - 6 } & $\mathrm{X} 3$ & .116 & .135 & .109 & .857 & .397 \\
\hline
\end{tabular}

a.Dependent Variable: $\mathrm{Y} 1$ 
International Journal of Economics, Business and Accounting Research (IJEBAR) .

Peer Reviewed - International Journal

Vol-2, Issue-3, 2018 (IJEBAR)

ISSN: 2614-1280, https://jurnal.stie-aas.ac.id/index.php/IJEBAR

The following are the results of the partial test (individual test) of each independent variable $(\mathrm{X})$ with $\mathrm{t}$ table $=0.2542$, then presented as follows:

\section{Partial Test Between Cultural} Variables $\left(\mathbf{X}_{1}\right)$ Against buying interest (Y)

To test the hypothesis used the $\mathrm{t}$ test which shows the partial effect of cultural variables $\left(\mathrm{X}_{1}\right)$ on the buying interest variable (Y) based on SPSS version 16 output obtained $t$ count of 3.138 greater than $\mathrm{t}$ table of 0.2512 , then $\mathrm{Ho}$ is rejected. In conclusion, partially cultural variables have an influence on buying interest. This is in accordance with Kotler's theory which says that Culture (cultur) is a basic determinant of one's desires and behavior. The results of this study are also confirmed by Ghoni and Bodroastutik's (2011) study which said that cultural factors have a partial effect on buying interest.

\section{Partial Test Between Social Variables} $\left(\mathrm{X}_{2}\right)$ Against Buying Interest (Y)

To test the hypothesis used the $t$ test which shows the effect of partial social variables $\left(\mathrm{X}_{2}\right)$ on the variable buying interest $(\mathrm{Y})$ based on SPSS version 16 output obtained t count of 3.360 greater than $t_{\text {table }}$ of 0.2512 , then Ho is rejected. In conclusion, partially social variables have an influence on buying interest. This is supported by Kotler's theory which says that social factors namely reference groups, families, as well as social roles and status influence consumer behavior. The results of this study were supported by Suprayetno et al. (2015). Which says that social factors have a partial effect on buying interest. However, it contradicts the research conducted by Santoso and Purwoasri in 2013 (2013) which said that social factors did not influence purchasing decisions.

\section{Partial Test Between Private Variables} $\left(\mathbf{X}_{3}\right)$ Against buying interest $(\mathbf{Y})$

To test the hypothesis used the $t$ test which shows the partial effect of personal variables $\left(\mathrm{X}_{3}\right)$ on the variable buying interest $(\mathrm{Y})$ based on SPSS version 16 output obtained $t$ count of 0.857 greater than $\mathrm{t}$ table of 0.2512 , then Ho is accepted. In conclusion, the private variables partially have no influence on buying interest. This is contrary to the research of Rachmat Mokhtar An Arsy (2014) which says that personal factors partially influence purchasing decisions. This is not influenced by the theory put forward by Kotler that buyer decisions are also influenced by personal characteristics. Personal factors include age and stages in the life cycle of the buyer, work and economy, personality and self-concept, and lifestyle and values

\section{Conclusions and Recommendations}

\subsection{Conclusion}

a. Cultural factors partially have a positive and significant effect on consumer buying interest in the English village rice milk stall pare.

b. Social factors partially have a positive and significant effect on consumer buying interest in the English village milk stick stall.

c. Personal factors partially have insignificant effect on consumer buying interest in the English village milk stick stall pare.

d. Cultural, social and personal factors have a simultaneous effect on consumers' buying interest in milk-stick stalls in the English village pare 
International Journal of Economics, Business and Accounting Research (IJEBAR) .

Peer Reviewed - International Journal

Vol-2, Issue-3, 2018 (IJEBAR)

ISSN: 2614-1280, https://jurnal.stie-aas.ac.id/index.php/IJEBAR

\subsection{Recommendation}

From this research, the suggestions that can be given by the author are as follows:

a. In terms of cultural factors, it is expected that milk stick stalls in the English village must be maintained in order to maintain a good image or view by providing services and maintaining the quality of products with good quality so that sales can continue to be improved.

b. For future research, it is expected to examine more deeply related to the consumption patterns of English village students with individual behavior.

\section{References}

Ardinal Muhammad. 2005. "Analisis Faktor Lingkungan terhadapa Keputusan Pembelian Telpon Genggam Di kalangan Mahasiswa Universitas Widayatama Bandung". Skripsi Fakultas Ekonomi Universitas Widayatama Bandung.

Kotler, p., adn Kevin Lane Keller. 2009. Manajemen Pemasaran, Edisi 13. Jilid 1. Erlangga. Jakarta.

Paul Peter, J., and Jerry C.Olson .2000. Consumer Behavior. Edisi 4. Cetakan 1. Eelangga. Jakarta.

Handayani dan M.Taufik. 2017. "Analisis Keputusan Konsumen Warung Angkringan Yang Dipengaruhi Lokasi, Fasilitas, dan Kualitas". Jurnal Ekonomi Manajemen dan Akuntansi.

Ujianto dan Abduracman. 2004. "Analisis Faktor - Faktor Yang Menimbulkan Kecenderungan Minat Beli Konsumen Sarung(Studi Perilaku Konsumen Sarung Di Jawa Timur)". Jurnal Manajemen Fakultas Ekonomi Universitas Kristen Petra.
Jimei. 2018. “Analisis Faktor- Faktor Yang Mepengaruhi Minat Beli Ulang Kosmetik Wardah(Studi Empiris Pada Mahasiswa Universitas Muhamadyah Surakarta)". Skripsi Fakultas Ekonomi Universitas Muhamady Surakarta. 